\title{
Computer Assisted Learning (CAL) in Mathematics and Personal Success of Elementary School Girls
}

\author{
KEY WORDS \\ mixed-gender \\ education, \\ achievement of girls, \\ differential attitudes \\ to boys \\ and girls, \\ computerized \\ assignments
}

\begin{abstract}
Noriany Orli, Computer Assisted Learning (CAL) in Mathematics and Personal Success of Elementary School Girls [Komputerowe wspomaganie uczenia się matematyki i sukces osobisty uczennic szkoły podstawowej]. Kultura - Społeczeństwo - Edukacja nr 2 (4) 2013, Poznań 2013, pp. 119-127, Adam Mickiewicz University Press. ISBN 978-83-232-2708-3. ISSN 2300-0422

Standardized tests administered nationwide in the fifth grade of the elementary school in Israel have shown that in the subject of mathematics boys achieve significantly higher scores than do girls. This gap is worrisome because of the importance of mathematical skills in success in education, both in the secondary school and in higher education, and in the job market. This paper briefly reviews a number of possible reasons for this gap, including lack of suitability to girls of current instruction methods in frameworks of mixed-gender education, deficiencies in mathematics training and math anxiety among teachers, gender stereotypes, and the phenomenon of the self-fulfilling prophecy. Then the paper outlines the researcher's proposed method, Computer Assisted Learning (CAL), for promoting girls' achievements in mathematics. Initial results have been promising.
\end{abstract}

In the mathematics lessons in the elementary school in Israel boys and girls learn together in one classroom. In the elementary school, it is not possible to place students into learning groupings, not according to grades and not according to gender. The learning is joint learning, heterogeneous: boys and girls learn together, in one class, in one lesson, with one teacher, and rarely with two teachers.

In the elementary school diverse needs are met. It is necessary to meet the needs of students with difficulties, average students, and strong and excelling students. The needs are met in an appropriate framework - whether in the framework of the class, in the framework of a small group, or in the framework of a larger 
group. Sometimes the response to needs is provided in the mathematics lessons, sometimes at the expense of another lesson, and sometimes at the end of the day. The possibilities are diverse and are adjusted to the students' age, to the need at hand, and to the system's needs.

The response given to the students in the elementary school is according to their achievements. Is this the way? Is this the method? Did anybody ever think to provide the response to the students according to their gender? Did anybody ever think to adjust the way of learning, practice, and construction of the material according to the students' gender?

There is a gap between the achievements of girls and boys (Bachar, 2012). Examination of the students' achievements in the elementary school in the Meyzav test (a test conducted nationwide with the goal of comparing the achievements of all students in the grade level) indicates an apparent difference between the grades of the girls and the boys. In the fifth grade the girls' scores are lower by 12 points than the boys' scores. The gap exists throughout the entire country in the fifth grade. The gap in the Meyzav is consistent, recurring in the different years the test has been administered.

Ayalon and Livnah (2013) addressed the gender gap in math and science achievements. Part of the solution will come in the field of national exams and in teachers' attitudes. The concept is that a student's experiences in school are more significant than the influence of society. Gender studies can shed light on the gender gap in the STEM (Science, Technology, Engineering, and Math) field. Beilock, Gunderson, Ramire, and Levine (2010) described girl students who are deterred from the STEM fields because of the stereotypes in society. In addition, the competition in the classroom can discourage girls from the STEM fields. Nosek et al. (2009) noted that the gender gap in the STEM field has declined over time in the United States. Gender stereotypes influence the gap in STEM and can influence its reduction. Nosek et al. (2009) also addressed the size of the gender gap, when the gap size and recognition of the gap are related to gender equalization. There are many debates over the reasons for gender differences. Kane and Merts (2012) considered that girls and boys may be born similar in their inherent intellectual potential and reviewed the factors that cause the changes and bring about the differences.

For years, we have known that the ways girls learn are different from the ways boys learn. We know that the methods used in the school are methods suited to boys. Bachar (2012) maintained that the learning method used in the classrooms is a competitive method and that the pedagogy recommended today focuses on learning by rote and algorithmic solving and not on comprehension. Both the employed learning method and the implemented pedagogy do not suit girls. The competitive method blocks the girls and stifles them. On the topic of pedagogy, girls learn to 
understand. Learning for comprehension requires time and a tolerant and patient climate that enables the student to ask questions, allows the topic to be discussed in-depth, and enables listening to one another. Teaching patterns that encourage competitiveness and algorithmic learning suit boys and in essence deprive the girls and their right to realize their full potential in the field of mathematics.

According to Professor Hazan (2010), girls' achievements improve when they learn in classes with other girls, without boys. She cited two explanations of this situation. First, there is the antiquated stereotype, which acts like a self-fulfilling prophecy. The stereotype speaks about girls' having lower abilities in the field of mathematics. Girls are aware of the stereotype, and thus they do less well, fulfilling the prophecy. The second explanation is boys' high and dominant evaluation of their abilities. Often boys are educated to evaluate themselves more highly than their true abilities, while, in contrast, the girls are educated to be modest.

The explanations posited by Hazan (2010) can help direct to a creative and desirable solution. Hazan wondered whether gender separation is the solution for the empowerment of girls.

Gray (2009) described a research study that determines that girls who learn in classes without boys attain higher achievements. However, she noted in her article that according to Dr. Miller, an educational psychologist, one of the solutions is separate classes in the schools with different teaching methods according to gender. In this way, through separate classes and different methods according to gender, members of each gender will realize their abilities.

Why should there be separate classes? Why not integrate different teaching methods in one class? Why not have teaching methods suited to members of both genders? Why not have different teaching methods suited to the nature of the students?

The methods existing in the schools today are more suited for boys. It is therefore important that we look for additional methods, creative methods, to be more suited for girls. When the school adopts a variety of methods, some of which are suited for boys and some for girls, then all students, regardless of gender, can realize their abilities in the method appropriate for them.

There is no argument over the fact that girls learn differently. Girls learn better through cooperation, through personal communication, and less through competitiveness and achievement-orientation (Kiran, 2009). It is clear that it is necessary to work differently with girls so that they will cooperate. It is necessary to create with girls a personal mode of communication that will grant them openness with competition and self-empowerment.

In the year 2013 the computer allows us to create such a mode of communication. My proposal is a creative proposal that connects to the existing situation and enriches it. Since the studies are held in a mixed-gender environment and since 
it is necessary to respond to the different needs, it is important in my opinion to provide an answer to the different learning methods and the different learning ways required for members of both genders. This answer will empower the learning experience of members of both genders and accordingly will promote their achievements.

The achievements are the product. I do not want to engage in the product but rather in the ways that led to it. A change in the ways that brought about this product will cause a change in the product. Change in the work method will necessarily lead to a change in the result. The thinking here is different; the action does not come from the result but from the way.

There is no doubt that the quality of the teachers teaching in the classes is one of the main factors influencing the successes and achievements. The Ministry of Education of Israel encourages teachers to study and attempts to train teachers to teach the subject. A document submitted to the Knesset, The Israeli Parliament (Knesset Research and Information Center, 2012) shows that in the elementary school the percentage of teachers trained to teach mathematics is $35 \%$. The datum itself is not high. It can be compared to the $18 \%$ of the teachers trained to teach the subject in the Ultra-Orthodox schools, the $33 \%$ trained to teach this subject in the state religious schools, and the $64 \%$ of the teachers trained to teach the subject in the non-Jewish state schools. In other words, the situation is in our hands and it is necessary to only have the will. It is possible to address the situation of the teachers' knowledge; we just have to want to do so.

The Ministry of Education puts the blame on the teachers. The teachers are to blame when the students fail in the tests. The teachers are to blame when there is a gap between boys and girls. The teachers are to blame when they are taught and trained to teach mathematics and they do not succeed. The Ministry of Education wanted to train teachers to teach mathematics. An article of the Teachers' Union (2004) described how the Ministry of Education opened centers of professionalization for teachers who teach the subject. Within a short period of time the centers were filled with teachers, without differentiation among them. There were teachers with knowledge in mathematics and teachers without it. A uniform curriculum was not created. Every center taught a different curriculum but the final test was the same. The unavoidable outcome was that some of the teachers were tested on topics they did not learn, and therefore some of the teachers failed the test. Then the story was told to the media...

The Ministry of Education had a good idea: it wanted only teachers trained in mathematics to teach the subject. The Ministry of Education wanted to reward teachers who would teach a number of classes and compensate them for the training they took. In actuality, the initiative did not succeed and today, at least in the elementary school, anybody who wants to teach the subject can do so. The 
Teachers Union released a new procedure according to which it is not possible to force a teacher to participate in training. A teacher participates in training only if he wants to do so. There is no doubt that following this decision additional difficulties in the system will ensue.

According to statements of the Minister of the Ministry of Education about the means of the teachers' scores in mathematics (in Detal, 2010), the data emphasize the severity of the problem of the quality of teachers in Israel. Many teachers do not teach the subject they learned in their academic studies. The Minister argued that in the past most of the teachers who taught in the elementary school had studied only 3 units of mathematics in the high school. These teachers do not have mathematical thinking, and therefore they cannot teach and develop such thinking in the children.

Bachar (2012) noted that teachers, regardless of their knowledge, tend to display a different attitude towards boys and girls. Boys are given more time than girls. Girls are addressed with more sensitive and forgiving expressions. Girls are forgiven for mistakes, while boys are pointed at the solution. Today it is known that gender differences do not exist in mathematical skills - gender differences in achievements are a result of education.

Bachar (2012) cited factors of success of boys and girls. Boys attribute their successes to their personal abilities and talents, while girls attribute their successes to investment, an easy test, a good teacher who explains the material well, luck, and so on. Girls do not mention the fact that they are intelligent and talented and that their abilities are on a high level. Here is the place to teach girls to do so. I am certain that we can succeed in teaching girls to attribute their successes to their personal abilities and to their high talents. It is all a matter of practice.

Bachar (2012) mentioned that girls typically prefer learning in groups, social learning, while the subject of mathematics is, for example, one of the subjects considered competitive and achievement-oriented. I am certain that it is possible to connect to this learning method and that it is possible to make the learning of mathematics into shared social learning. The solution lies in the approach. A change in the approach will change the attitude towards girls. A change of the study method will empower the girls and the women teachers. A change of the method will contribute to both parties, both girls and women teachers, and to the relationship between them.

Teachers in the elementary school are often women teachers. Beilock, Gunderson, Ramire, and Levine (2010) discussed fear of math and the anxiety about doing math. The achievements of people who are afraid of math are low. When the teachers in the elementary school have math anxiety, they have negative feelings towards math, and thus there is an impact on the achievements of the girls in the teachers' class. Beilock, Gunderson, Ramire, and Levine (2010) 
noted that in the research the women teachers with the higher math anxiety had the most girls with lower math achievements - but not boys. The girls are 'infected' by their teacher's knowledge and feelings. Therefore, pedagogy should address the women teachers who do not have degrees in math and their fear and anxiety of math and accordingly thus give the girls the opportunity to succeed and to increase their achievements.

Last year, as a teacher of mathematics of fourth, fifth, and sixth grades, I decided to create a different communication with the students. I gave computerized tasks for work at home. There were summative tasks, like home tests. The students had to prove comprehension and implementation of what was learned in diverse ways. The students all were given my email and the tasks. It was possible to work with others, friends, family members, neighbors, private tutors, and websites. The students had to perform the tasks and reflect those they solved them with. I combined different subjects in the learning and allowed the diverse use of creativity.

The result was amazing. The response was amazing. A steadily increasing number of girls reflected that this method was comfortable for them. The possibility of sending an email, at any opportunity, to communicate personally, to ask questions, and to feel comfortable, since this in an individualized method that others do not see, worked wonders. We opened a special channel of communication. The very fact that the students could receive help privately caused the girls to rise to the challenge and become creative. A steadily increasing number of girls cooperated. The girls invested effort in the assignments, worked creatively in the studied areas, and invested in the subject.

The message that was conveyed was that tests can also be different. The end of the topic does not have to be a test that encompasses all the exercises in writing but can be a project on the topic that can be undertaken in the group. It is necessary to use the acquired knowledge, to implement it creatively; this is the essence of learning.

The children were given some assignments to prepare in groups, some to prepare individually. Time was given to do the assignments, and it was possible to get help and to produce wonderful products. The process of the work caused students to create impressive products that they were proud of and interested in displaying, so we had lessons devoted to the presentation of the products.

This method empowered many girls but not only them. Lo and behold, this method also suited some of the boys. In a test I held at the end of the year, the students' scores rose, both the girls' scores and the boys' scores. It was apparent that the girls had greater mastery of the topics. Their confidence and enjoyment in the subject increased amazingly.

Is this the method? Is this the solution? Is the way to find methods that will suit members of both genders who are learning in a mixed-gender class? Is the method 
to direct to the way and not to the products? Will the change in the work method result in a change in products? In my opinion, the answer is a resounding 'yes', especially if we wisely introduce into the change the ways accepted in the school, namely localized responses to difficulties in small or larger groups, according to the existing threshold.

So what did we have here? We had data of lower achievements of girls, we had girls who did not realize their potential, we had teachers who do not always come from the subject and are not always properly trained, we had stereotypes in society, and since most of the teachers in the elementary school are women, the stereotype is introduced into the school as a self-fulfilling prophecy. The decision was to use the existing data and with them to create success. The decision was to approach the process and not the products.

I chose the name CAL, Computer Assisted Learning. The idea is that computer assisted learning in mathematics will cause girls to succeed. Through computerized communication, private and non-threatening, I can create a meaningful relationship with the students, and especially with the girls, who feel more comfortable in this method than in the class, where they feel less comfortable asking questions and demonstrating lack of knowledge in front of other students.

The thought was that change of the work method with the girls will help empower them. The empowerment will boost their achievements and their self-confidence. The idea was to create a cycle that will promote their motivation, increase desire to create, do, and communicate, and cause further success.

There is no doubt that such a success can close the gap in achievements between girls and boys. I again stress that the method is suited not only for girls but also for many boys. The magic path is to combine both ways - the way used today and the creative way I formed.

The advantages and disadvantages of mixed-gender education caused me to create computerized assignments that have the goal of increasing girls' achievements and combining diverse ways of learning so as to empower the learners.

\section{Literatura}

Ayalon H., Livnah I. (2013). Educational Standardization and Gender Differences in Mathematics Achievement: A Comparative Study. „Social Science” 42, s. 432-445

Bachar S. (2012). Gender and Gender Equality in Education, To Study Scientific and Technological Subjects in Gender Segregation. http://cms.education.gov.il/EducationCMS/Units/ Shivion/MaagareyMeida/MaamarimVeavodot/MadaVetechnologyaBehafradaMigdarit. htm (Hebrew)

Beilock S.L., Gunderson E.A., Ramire G., Levine, S.C. (2010). Female Teachers Math Anxiety Affects Girls Math Achievement. „PNAS” February 2, Vol. 107, No. 5, s. 1860-1863 
Detal L. (2010). Scores of Grades of Teachers of Mathematics: 76.7, 15\% Failed at Professionalization. The Marker, December 20. http://www.themarker.com/career/1.587398 (Hebrew)

Gray M. (2009). Only Girls in the Class - Higher Achievements. http://www.mako.co.il/homefamily-kids/education/Article-5a90efde95e2021006.htm March 22. (Hebrew)

Hazan O. (2010). Gender Segregation: For and against. On the Agenda: The Female Angle. http:// www.asimon.co.il/ArticlePage.aspx?AID=8185\&AcatID=81\#At (Hebrew)

Kane J.M., Merts J.E. (2012). Debunking Myths about Gender and Mathematics Performance. „Notices of the AMS” Vol. 59, No. 1

Kiran C. (2009). How Gender Affects Learning, A Virginia School Separates Students by Gender to Improve Learning. http://www.youtube.com/watch? $\mathrm{v}=$ evJOwzyLjJA\#t $=184$

Knesset Research and Information Center (2012). Correlation between Field Training of Teachers Teaching Field - Situation Report. http://www.knesset.gov.il/mmm/data/pdf/m03139.pdf

Nosek B.A. et al. (2009). National Differences in Gender-Science Stereotypes Predict National Sex Differences in Science and Math Achievement. „PNAS“. June 30, Vol. 106. No 26. s. $10593-10597$

Teachers Union (2004). Who in Hell Is Responsible for This Failure? Free Lesson, 64, November. http://www.itu.org.il/?CategoryID=574\&ArticleID=2035 (Hebrew)

\section{Komputerowe wspomaganie uczenia się matematyki i sukces osobisty uczennic szkoły podstawowej}

\section{Streszczenie}

W szkołach podstawowych w Izraelu podczas lekcji matematyki chłopcy i dziewczęta uczą się razem w jednej klasie. Nie ma możliwości rozdzielenia uczniów według osiągnięć lub płci. Edukacja jest wspólna dla wszystkich: chłopcy i dziewczęta uczą się razem w jednej klasie $\mathrm{z}$ jednym nauczycielem, czasem przy wsparciu drugiego.

Szkoła podstawowa to miejsce zaspokajania różnorodnych potrzeb edukacyjnych - mamy do czynienia z różnymi uczniami: z trudnościami w uczeniu się, „średniakami” oraz z dobrymi i wybitnymi. Dokonuje siętego między innymi poprzez organizację pracy w małych lub większych grupach. Nie zawsze reagujemy adekwatnie do ich potrzeb w trakcie lekcji matematyki, czasami dzieje się tak kosztem innych lekcji, czasami dopiero w czasie zajęć pozaszkolnych. Możliwości są zróżnicowane, wykorzystuje się różne sposoby pracy - dostosowane do wieku uczniów oraz do potrzeb systemu szkolnego.

Czy jednak ktokolwiek kiedykolwiek zadał sobie pytanie: czy nie należałoby dostosować systemu do płci uczniów? Tak, by dostosować sposób nauczania - uczenia się, praktykę i konstrukcję treści do płci uczniów?

Standaryzowane testy przeprowadzane od lat w piątych klasach szkoły podstawowej w całym Izraelu pokazują, że chłopcy osiągają znacznie lepsze wyniki w matematyce niż dziewczęta. Luka ta jest niepokojąca ze względu na znaczenie umiejętności matematycznych dla sukcesu edukacyjnego zarówno w szkole średniej, jak i na studiach oraz dla osiągnięcia sukcesu na rynku pracy.

W artykule opisano kilka możliwych powodów tej luki, w tym brak przydatności obecnych metod nauczania dla dziewcząt w koedukacyjnych klasach, braki w wyszkoleniu nauczycieli matematyki, stereotypy płci oraz zjawisko samospełniającej się przepowiedni. Autor artykułu 
przedstawia propozycję autorskiej metody w nauczania matematyki - metodę komputerowego wspierania uczenia się matematyki („Computer Assisted Learning, CAL), służącą poprawie osiągnięć dziewcząt w matematyce.

Zmiana sposobu pracy z uczennicami powinna służyć ich wzmocnieniu, dodaniu im pewności siebie i poprawie ich wyników. Nie ma wątpliwości, że taki sukces może wypełnić lukę w osiągnięciach matematycznych dziewcząt i chłopców. Wstępne wyniki są obiecujące. 